\title{
Cryptobacterium curtum gen. nov., sp. nov., a new genus of Gram-positive anaerobic rod isolated from human oral cavities
}

\author{
Futoshi Nakazawa, ${ }^{1}$ Sergio E. Poco, ${ }^{1}$ Tetsuro Ikeda, ${ }^{1}$ Michiko Sato, ${ }^{1}$ \\ Sotos Kalfas, ${ }^{2}$ Göran Sundqvist ${ }^{3}$ and Etsuro Hoshino ${ }^{1}$
}

Author for correspondence: Etsuro Hoshino. Tel: +81 25227 2838. Fax: +81252270806.

e-mail: hoshino@dent.niigata-u.ac.jp

1 Department of Oral Microbiology, School of Dentistry, Niigata University, Niigata, 951-8514, Japan

2,3 Departments of Oral Biology ${ }^{2}$ and Endodontics ${ }^{3}$, School of Dentistry, University of Umeå, Umeå, Sweden

\begin{abstract}
Novel Eubacterium-like isolates, strains $12-3^{\top}$ and KV43-B, which were isolated from the periodontal pocket of an adult patient with periodontal disease and necrotic dental pulp, respectively, were studied taxonomically and phylogenetically. The morphological and differential biochemical characteristics of these organisms are also described in this paper. These organisms were Gram-positive, anaerobic, non-spore-forming, rod-shaped bacteria that were inert in most of the conventional biochemical tests and closely resembled members of asaccharolytic oral Eubacterium species. On the other hand, protein profiles of whole cells in SDS-PAGE and Western immunoblotting reaction analysis distinguished these isolates from strains of the previously described genus Eubacterium. The G+C content of the DNAs from the novel isolates was 50 and 51 mol\%, respectively. The levels of DNA-DNA relatedness to other asaccharolytic oral Eubacterium species, including Eubacterium brachy, Eubacterium lentum, Eubacterium nodatum, Eubacterium timidum, Eubacterium saphenum, Eubacterium minutum and Eubacterium exiguum, was less than $11 \%$. These organisms also exhibited a very low level of reassociation with the DNA of Eubacterium limosum, the type species of the genus Eubacterium. The results of 16S rDNA sequence comparisons revealed that these organisms represent a novel lineage distinct from all previously described genera of Gram-positive, rod-shaped bacteria. On the basis of our results, it is suggested that strains $12-3^{\top}$ and KV43-B should be classified in a new genus and species, for which the name Cryptobacterium curtum gen. nov., sp. nov. is proposed. The type strain of Cryptobacterium curtum is $12-3^{\top}$ ( = ATCC 700683').
\end{abstract}

Keywords: Cryptobacterium curtum gen. nov., sp. nov., DNA-DNA relatedness, 16S rDNA sequence, phylogenetic analysis

\section{INTRODUCTION}

The genus Eubacterium comprises Gram-positive, anaerobic, non-spore-forming, rod-shaped bacteria (Moore \& Moore, 1986). Several species of Eubacterium have been documented as the aetiological agents of chronic periodontitis (Hill et al., 1987; Holdeman et al., 1980; Martin et al., 1986; Moore et al., 1982, 1983, 1985; Slayne \& Wade, 1994; Uematsu \& Hoshino,

The DDBJ/EMBUGenBank accession number for the 165 rRNA gene sequence of strain $12-3^{\top}$ is $A B 019260$.
1992; Wade et al., 1992) based on frequent isolation from diseased periodontal sites. The pathogenic role of these species was indicated by their incidence in cultures of subgingival periodontitis samples (as high as $54 \%$; Tolo \& Schenck, 1985) and in the cultivable flora in the subgingival sites (as high as $57 \%$ ) and their infrequent isolation from adjacent supragingival areas (Hill et al., 1987). In addition, antibody titres against Eubacterium species in the serum of patients with periodontitis are higher than those of healthy persons, suggesting that these bacteria cause immunological reactions in periodontal lesions (Gunsolley et al., 1990; Sato et al., 1998; Tew et al., 1985; Tolo \& Jorkjend, 
1990; Tolo \& Schenck, 1985). Moreover, they have been recognized as pathogens in oral and dental infections, such as advanced caries (Ando \& Hoshino, 1990; Edwardsson, 1974; Hoshino, 1985), pulpal infections (Hoshino et al., 1992; Sato et al., 1993) and dentoalveolar abscesses (Wade et al., 1994) and also from non-oral, clinically significant infections, such as head and neck infections, abdominal infections (Brook \& Frazier, 1993), bacteraemia associated with malignancy (Fanstein et al., 1989) and genital tract infections associated with intrauterine devices (Brook, 1983).

Historically, the definition of genus Eubacterium, on the basis of negative fermentation characteristics, has provided a convenient classification for a collection of diverse organisms. From the nature of the definition, it was inevitable that there was considerable heterogeneity among the species which were placed in this genus and it now contains many species and groups which are phylogenetically unrelated (Cheeseman et al., 1996; Moore \& Moore, 1986;Nakazawa \& Hoshino, 1994). In recent years, many oral asaccharolytic isolates have been described, some of which qualify as members of the genus Eubacterium but could not be assigned to any of the named species (Cheeseman et al., 1996; Poco et al., 1996a, b; Sato et al., 1998).

A recent study in our laboratory has shown that reference strains, including strains $12-3^{\mathrm{T}}$ and KV43-B, of oral asaccharolytic Eubacterium species are distinguished by RFLP analysis of 16S rDNA amplified by PCR, using endonucleases $H p a \mathrm{II}$ and $A l u \mathrm{I}$ (Sato et al., 1998). In this paper, a polyphasic approach was used to characterize these unnamed strains, $12-3^{\mathrm{T}}$ and KV43-B, which could not be classified as any of the previously established species. We report here the results of conventional biochemical tests including whole-cell protein profile analysis, Western immunoblotting analysis, DNA base composition analysis, DNA-DNA hybridization studies and 16S rDNA sequence comparisons. On the basis of our results and the taxonomic properties of the organisms, we conclude that strains $12-3^{\mathrm{T}}$ and KV43-B may represent members of a new genus and a new species, for which we propose the name Cryptobacterium curtum.

\section{METHODS}

Bacterial strains and culture conditions. The bacterial strain $12-3^{\mathrm{T}}$ was isolated in our laboratory from a human periodontal pocket sample (Sato et al., 1998). Strain KV43-B was isolated from necrotic dental pulp (Sundqvist, 1976). The type strains of previously established asaccharolytic Eubacterium species, together with the more recently proposed species Eubacterium minutum (Poco et al., 1996a) and Eubacterium exiguum (Poco et al., 1996b), were included in this study. Eubacterium infirmum and Eubacterium tardum (Cheeseman et al., 1996) were not examined in this work but are discussed. All of the strains were cultured on brain-heart infusion (BHI)-blood agar plates for 7-10 d under strictly anaerobic conditions in an anaerobic glove box (model AZ-Hard; Hirasawa) containing $80 \% \mathrm{~N}_{2}, 10 \%$
$\mathrm{H}_{2}$ and $10 \% \mathrm{CO}_{2}$. The bacterial cells were harvested by centrifugation, washed with PBS (136 mM NaCl, $10 \mathrm{mM}$ sodium phosphate, $\mathrm{pH} 7 \cdot 2$ ), and stored at $-20^{\circ} \mathrm{C}$ until use. To ensure strictly anaerobic conditions in the box, the reduction of methyl viologen (at $-446 \mathrm{mV}$ ) was carefully checked when experimental procedures were carried out.

Morphological and biochemical characteristics. Cellular morphology was determined by examining cells grown on BHI-blood agar plates. Biochemical reactions were tested by the methods described previously (Holdeman et al., 1977). End products produced in peptone-yeast extractglucose broth (PYG) were assayed by GC as described previously (Hoshino \& Sato, 1986).

Electron microscopy. Transmission electron microscopy was used for cell wall characterization. Cultures $(48 \mathrm{~h})$ were fixed in a solution of $2.5 \%$ glutaraldehyde in $0.1 \mathrm{M}$ phosphate buffer, pH 7.4, for $1 \mathrm{~h}$ at $4^{\circ} \mathrm{C}$. The cells were centrifuged and washed three times with the same buffer. They were post-fixed with $1 \%$ osmic acid for $18 \mathrm{~h}$ at $4{ }^{\circ} \mathrm{C}$ and dehydrated for $10 \mathrm{~min}$ each with $50,75,90,95$ and $100 \%$ ethanol. Preparations were washed with $33.3,66.6$ and $100 \%$ epoxy resin in propylene oxide for $60 \mathrm{~min}$ and then embedded in $100 \%$ epoxy resin. After hardening, ultrathin sections were cut with a diamond knife, and then stained with uranyl acetate and lead citrate. The thin sections were studied with a Hitachi H-600A electron microscope.

Whole-cell protein profiles. Cellular protein profiles were examined by SDS-PAGE analysis as described previously (Laemmli, 1970). Approximately $50 \mathrm{mg}$ (wet wt) whole cells were washed three times in $1 \mathrm{ml}$ distilled water and suspended in $150 \mu$ l lysis buffer containing $4 \%(\mathrm{w} / \mathrm{v}) \mathrm{SDS}, 40 \%$ (v/v) glycerol, $10 \%(\mathrm{v} / \mathrm{v})$ 2-mercaptoethanol and $0.25 \mathrm{M}$ Tris $/ \mathrm{HCl}$ ( $\mathrm{pH} \mathrm{6.8)}$. The suspensions were boiled for $10 \mathrm{~min}$ and then centrifuged at $12000 \mathrm{~g}$ for $10 \mathrm{~min}$. The protein concentrations of the supernatants were measured by a protein assay kit (Bio-Rad). The supernatants $(10 \mu \mathrm{g}$ of each) were subjected to electrophoresis on a $12.5 \%$ polyacrylamide gel by using a model KS-8010 Micro slab gel electrophoresis system (Marysol). After electrophoresis, the gel was stained with Coomassie brilliant blue R-250.

Western immunoblotting analysis. Proteins were transferred from SDS-PAGE gels to a nitrocellulose membrane (pore size, $0.45 \mu \mathrm{m}$; Bio-Rad) by using the transfer buffer system described previously (Burnette, 1981), in conjunction with the transblot system (Marysol) at a constant current of $350 \mathrm{~mA}$ with cooling for $4 \mathrm{~h}$. Membranes were processed with slight modification as described previously (Nakazawa \& Hoshino, 1993). Briefly, an immune rabbit antiserum $(1: 1000)$ was used as first antibody followed by incubation with goat anti-rabbit immunoglobulin $G$ conjugated with peroxidase $(1: 1000)$ as the second antibody. The colour was then developed.

DNA isolation and base composition analysis. DNA was isolated and purified following a modification of the Marmur protocol (Marmur, 1961; Nakazawa \& Hoshino, 1994). The $\mathrm{G}+\mathrm{C}$ content of DNA was determined by HPLC, as described previously (Katayama-Fujimura et al., 1984).

DNA-DNA hybridization analysis. DNA-DNA hybridization was performed by the membrane filter method as described previously (Meyer \& Schleifer, 1978). Briefly, reference DNA was labelled by using a multiprime DNA labelling kit (Amersham) and $\left[\alpha_{-}^{32} \mathrm{P}\right] \mathrm{dCTP}$, and then purified with a Nick column (Pharmacia LKB). About $40 \mu \mathrm{g}$ unlabelled 
single-stranded DNA immobilized on each nitrocellulose membrane filter and $0.015 \mu \mathrm{g}$ labelled reference DNA were reassociated in a solution containing $0.08 \%$ SDS, $0.02 \%$ polyvinylpyrrolidone, $0.02 \%$ Ficoll 400 , BSA (Fraction V; Sigma) and $1 \mathrm{ml} 6 \times \mathrm{SSC}(1 \times \mathrm{SSC}$ is $0.15 \mathrm{M} \mathrm{NaCl}$ plus $0.015 \mathrm{M}$ sodium citrate). After incubation overnight at $60{ }^{\circ} \mathrm{C}$, the filters were washed and dried. The radioactivity was measured with a liquid scintillation counter. Triplicate tests were performed for each assay and the results were normalized to $100 \%$ for the homologous DNA.

Sequencing of the 16S rRNA gene and phylogenetic analysis. The 16S rRNA gene was amplified by PCR with a nucleotide primer set [5'-AGA GTT TGA TCM TGG CTC AG-3', located at positions 8-27 (Escherichia coli numbering) and 3'-TTC AGC ATT GTT CCA TYG GCAT-5', located at positions 1492-1513 (E. coli numbering)]. The PCR reaction was performed with Premix Taq (Takara) according to the manufacturer's instructions (Fukunaga et al., 1995) in a thermal controller (model PTC-100; MJ Research). The DNA fragment obtained by PCR amplification was sequenced by using a Thermo Sequenase Fluorescent Labelled Primer Cycle Sequencing kit (Amersham) and a series of custom-synthesized primers with ALFexpress DNA sequencer (Pharmacia LKB) according to the manufacturer's instructions. The sequences were aligned with each other and connected by using SEQMAN II of the LASERGENE program (DNASTAR). Programs MEGalign of LASERGENE, CLUSTAL W and NJPLOT were used to compare sequences and to construct an evolutionary tree by the neighbour-joining method. Also, confidence intervals were assessed by NJPLOT and CLUSTAL $\mathrm{W}$ with bootstrap analysis.

Nucleotide sequence accession numbers. The accession numbers for the reference sequences used in this study are shown in Fig. 3.

\section{RESULTS AND DISCUSSION}

\section{Morphological and biochemical characteristics}

Strains $12-3^{\mathrm{T}}$ and KV43-B were non-spore-forming, non-motile, strictly anaerobic, very short rod-shaped $(0.4$ by $0.8-1.0 \mu \mathrm{m})$ organisms. Ultrathin sections showed a single-layered cell wall of about $10 \mathrm{~nm}$ in thickness (Fig. 1), which is typical of Gram-positive bacteria. The cell wall was tightly fitted to the cytoplasmic membrane. The cells divided after septum formation that was initiated peripherally. Pili- or flagella-like structures were not found. The growing cells were Gram-positive, but sometimes cells in older cultures were Gram-negative. Growth in broth media was very poor with or without carbohydrates. These organisms formed tiny colonies on BHI-blood agar plates of about $0.3-0.5 \mathrm{~mm}$ in diameter that were circular, convex and translucent. Even after prolonged incubation, the colonies were less than $1 \mathrm{~mm}$ in diameter, which is typical of oral asaccharolytic Eubacterium species. No haemolysis occurred around colonies on BHI-blood agar plates. Strains $12-3^{\mathrm{T}}$ and KV43-B were asaccharolytic because they did not ferment glucose and other carbohydrates. They were positive for arginine hydrolysis and inert in most of the conventional tests (Table 1). Nitrate reduction was negative and they did not hydrolyse aesculin, starch or

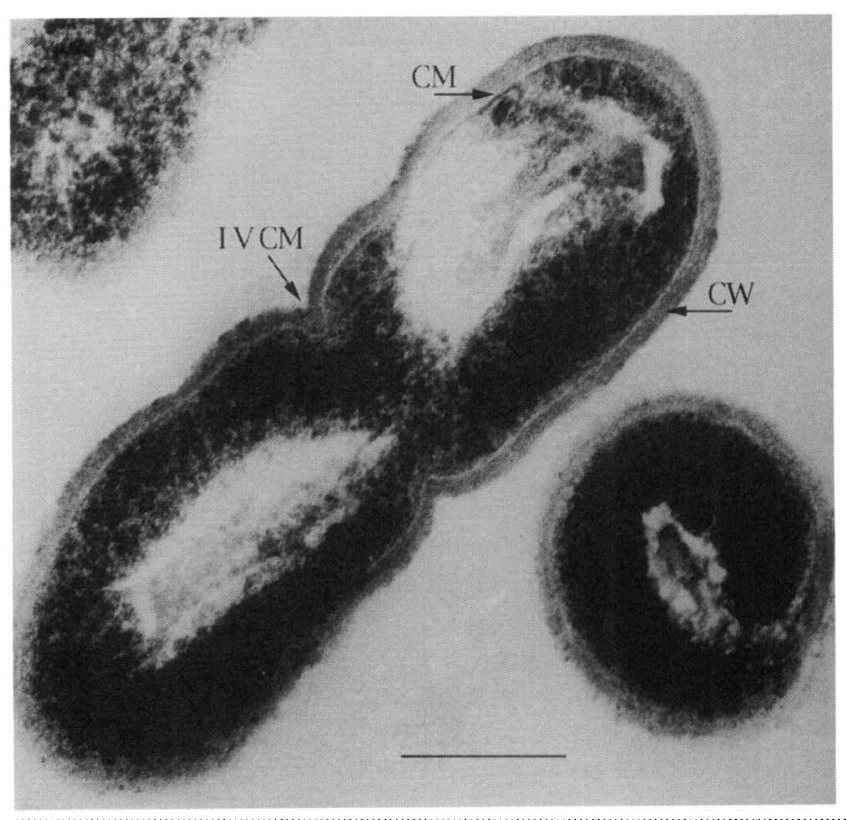

Fig. 1. Transmission electron microphotograph of a thin section of cell of Cryptobacterium curtum 12-3 $\left(=\right.$ ATCC $700863^{\top}$ ) showing the Gram-positive cell wall. Bar, $200 \mathrm{~nm}$. Cell wall (CW), cytoplasmic membrane (CM) and invagination of cytoplasmic membrane before cell divisions (IVCM) are indicated.

gelatin. In addition, they did not produce indole, ammonia, urease or catalase. When assayed by GC, these strains did not produce any metabolic end product in PYG medium. Among the previously described oral asaccharolytic Eubacterium species, they phenotypically resembled E. exiguum and Eubacterium lentum, which also did not produce any end product (Poco et al., 1996a, b). They are phenotypically distinct from the acetate- and butyrateproducing asaccharolytic Eubacterium species, such as Eubacterium nodatum (Moore \& Moore, 1986), Eubacterium saphenum (Uematsu et al., 1993), E. minutum (Poco et al., 1996b), E. tardum and E. infirmum (Cheeseman et al., 1996).

\section{Whole-cell protein profiles and Western immunoblotting analysis}

The protein profiles of the two strains, which were produced by SDS-PAGE analysis, had major bands in the region of 80,50 and $45 \mathrm{kDa}$ (Fig. 2). By visual analysis, the oral asaccharolytic Eubacterium species each showed typical profiles and no major bands were common indicating great heterogeneity in polypeptide components. Western blotting reactions (Table 2) with rabbit antisera revealed that antigens of strain $12-3^{\mathrm{T}}$ did not react with the antisera raised against the reference oral asaccharolytic species, whereas antigens from the previously described species were recognized by their respective antisera. 
Table 1. Comparison of biochemical characteristics and enzymic profiles

None of the strains fermented glucose.

\begin{tabular}{|lccc|}
\hline \multicolumn{1}{|c}{ Taxon } & End product* & $\begin{array}{c}\text { Arginine } \\
\text { hydrolysis }\end{array}$ & $\begin{array}{c}\text { Nitrate } \\
\text { reduction }\end{array}$ \\
\hline Cryptobacterium curtum & - & + & - \\
Eubacterium lentum & - & + & + \\
Eubacterium timidum & phe-a & - & - \\
Eubacterium exiguum & - & + & - \\
Eubacterium minutum & B or b & - & - \\
Eubacterium nodatum & a, B & + & - \\
Eubacterium saphenum & a, b & - & - \\
Eubacterium brachy & ib, ic, iv, phe-p & - & - \\
\hline
\end{tabular}

* End product when grown on PYG medium. a, Acetate; b, butyrate; ib, isobutyrate; ic, isocaproate; iv, isovalerate; phe-a, phenylacetate; phe-p, phenylpropionate. Upper-case letters represent an amount of product equal to or more than $10 \mathrm{mM}$ and lower-case letters represent less than $10 \mathrm{mM}$.

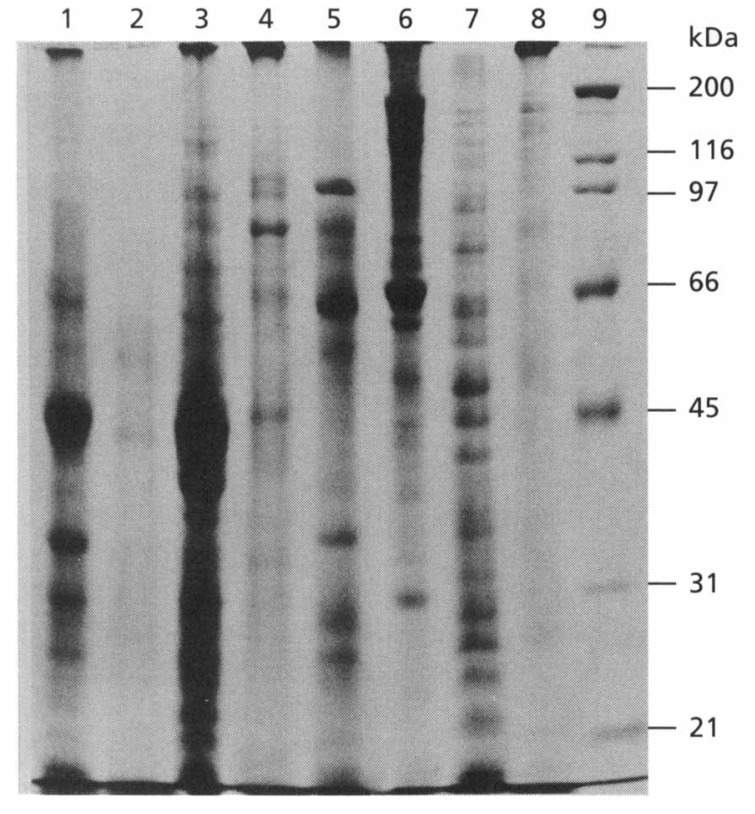

Fig. 2. Protein profiles of $E$. exiguum ATCC $700122^{\top}$ (lane 1), $E$. lentum ATCC $25559^{\top}$ (lane 2), E. brachy ATCC $33089^{\top}$ (lane 3), $E$. nodatum ATCC $33099^{\top}$ (lane 4), E. timidum ATCC $33093^{\top}$ (lane 5), E. minutum ATCC $700079^{\top}$ (lane 6), Cryptobacterium curtum $12-3^{\top}$ (= ATCC $700863^{\top}$, lane 7), E. saphenum ATCC $49989^{\top}$ (lane 8 ) and molecular mass markers (lane 9; in $\mathrm{kDa}$ ) on a $12.5 \%$ SDS-polyacrylamide gel.

The present study clearly showed that strains $12-3^{\mathrm{T}}$ and KV43-B could be distinguished from the reference species by their protein components, including the structural proteins of the whole bacterial cells, and immunological reactions. These data are consistent with the previously published data of Nakazawa \& Hoshino (1993).

\section{DNA base composition}

As previously reported (Nakazawa \& Hoshino, 1993, 1994; Poco et al., 1996a, b), the G + C contents of oral asaccharolytic Eubacterium species range from 38 to $62 \mathrm{~mol} \%$, as determined by HPLC (Table 3). The $\mathrm{G}+\mathrm{C}$ content of strains $12-3^{\mathrm{T}}$ and $\mathrm{KV} 43-\mathrm{B}$ were 50 and $51 \mathrm{~mol} \%$, respectively, which are at the same level as Eubacterium timidum or Eubacterium limosum (both $50 \mathrm{~mol} \%$ ), the latter of which is the type species of the genus Eubacterium.

\section{DNA-DNA hybridization analysis}

The DNA-DNA hybridization experiments as measured by the membrane filter method are listed in Table 3. The DNA of strain $12-3^{\mathrm{T}}$ exhibited a high level of reassociation with the DNA of strain KV43-B $(97 \%)$, suggesting that they are related genetically. Moreover, the DNAs of the other Eubacterium species, including the type species of the genus Eubacterium, $E$. limosum, showed very low levels of reassociation with the DNAs of strains $12-3^{\mathrm{T}}$ and KV43-B (1-11\%). Also, the DNAs of strains $12-3^{\mathrm{T}}$ and KV43-B exhibited low levels $(1-2 \%)$ of DNA relatedness to two previously unnamed asaccharolytic Eubacterium-like strains D2-18 and D5-2 (data not shown). These DNA-DNA hybridization data clearly showed that levels of homology among these strains were low indicating that all the species examined were not closely related, further confirming the data of Nakazawa \& Hoshino (1994) and Sato et al. (1998).

\section{5 rRNA gene sequence and phylogenetic analysis}

The 16S rRNA gene sequence of strain $12-3^{\mathrm{T}}$ (1429 bases in length) was determined in order to establish its precise phylogenetic affiliation. The $16 \mathrm{~S}$ rRNA gene 
Table 2. Western blotting reactions of Cryptobacterium curtum and other oral asaccharolytic Eubacterium taxa

Species: 1, Eubacterium timidum; 2, Eubacterium minutum; 3, Eubacterium brachy; 4, Eubacterium lentum; 5, Eubacterium nodatum; 6, Eubacterium saphenum. +, Positive; -, negative; w, weakly positive.

\begin{tabular}{|c|c|c|c|c|c|c|}
\hline \multirow[t]{2}{*}{ Antigen } & \multicolumn{6}{|c|}{ Reaction with antisera against species: } \\
\hline & 1 & 2 & 3 & 4 & 5 & 6 \\
\hline Cryptobacterium curtum $12-3^{\mathrm{T}}$ & - & - & - & - & - & - \\
\hline Eubacterium timidum ATCC $33093^{\mathrm{T}}$ & + & - & - & - & - & \\
\hline Eubacterium minutum ATCC $700079^{\mathrm{T}}$ & - & + & - & - & - & - \\
\hline Eubacterium brachy ATCC $33089^{\mathrm{T}}$ & - & - & + & - & - & - \\
\hline Eubacterium lentum ATCC $25559^{\mathrm{T}}$ & - & - & $\mathrm{w}$ & + & - & - \\
\hline Eubacterium nodatum ATCC $33099^{\mathrm{T}}$ & - & - & - & - & + & - \\
\hline Eubacterium saphenum ATCC 49989 & - & - & - & - & - & + \\
\hline Eubacterium exiguum ATCC $700122^{\mathrm{T}}$ & - & - & - & w & $\mathrm{w}$ & - \\
\hline
\end{tabular}

Table 3. DNA base compositions and levels of DNA relatedness to oral asaccharolytic Eubacterium species

\begin{tabular}{|c|c|c|c|}
\hline \multirow[t]{2}{*}{ Source of DNA } & \multirow[t]{2}{*}{$\mathbf{G}+\mathrm{C}(\mathrm{mol} \%)^{*}$} & \multicolumn{2}{|c|}{$\begin{array}{l}\text { Homology (\%) with } \\
\text { labelled DNA from: } \dagger\end{array}$} \\
\hline & & $12-3^{T}$ & KV43-B \\
\hline Cryptobacterium curtum $12-3^{\mathrm{T}}$ & 51 & 100 & \\
\hline Cryptobacterium curtum KV43-B & 50 & 97 & 100 \\
\hline Eubacterium exiguum ATCC $700122^{\mathrm{T}}$ & 60 & 6 & 11 \\
\hline Eubacterium minutum ATCC $700079^{\mathrm{T}}$ & $38-40$ & 2 & 4 \\
\hline Eubacterium timidum ATCC $33893^{\mathrm{T}}$ & 50 & 2 & 5 \\
\hline Eubacterium nodatum ATCC $33099^{\mathrm{T}}$ & 41 & 1 & 2 \\
\hline Eubacterium lentum ATCC $25559^{\mathrm{T}}$ & 62 & 5 & 9 \\
\hline Eubacterium brachy ATCC $33089^{\mathrm{T}}$ & 39 & 1 & 4 \\
\hline Eubacterium saphenum ATCC $49989^{\mathrm{T}}$ & 45 & 2 & 4 \\
\hline Eubacterium limosum ATCC $8486^{\mathrm{T}}$ & 50 & 2 & 4 \\
\hline
\end{tabular}

${ }^{*} \mathrm{G}+\mathrm{C}$ contents were determined by HPLC.

$\dagger$ All values were normalized to $100 \%$ for the homologous reactions.

sequence of E. minutum ATCC $700079^{\mathrm{T}}$ (1456 bases in length) was also aligned for comparison together with other Eubacterium species. The sequences were compared with those of other asaccharolytic Eubacterium species, including Eubacterium brachy, $E$. nodatum, $E$. timidum, E. saphenum, E. tardum and E. infirmum, and other related Gram-positive bacteria selected from the GenBank database by the sequence similarity search using the BLAST and FASTA algorithms. A database search revealed that strain $12-3^{\mathrm{T}}$ belongs to the actinomycetes of the Gram-positive bacteria and its 16S rRNA sequence may be most similar to that of members of the family Actinomycetaceae in the order Actinomycetales. On the basis of the sequence similarity matrix data, an evolutionary tree was constructed by using the MEGALIGN program (Fig. 3).
According to this tree, strains $12-3^{\mathrm{T}}$ and KV43-B could be distinguished from these asaccharolytic $\mathrm{Eu}$ bacterium species. These phylogenetic data completely agree with previous results which are obtained by RFLP analysis of 16S rDNA from asaccharolytic Eubacterium species (Sato et al., 1998). Our analysis also indicates that the novel strain belongs to a large group of the Actinomycetes, although it does not belong to any taxa. Strain $12-3^{\mathrm{T}}$ formed a cluster with Coriobacterium glomerans and Denitrobacterium detoxificans. However, it showed distinct lines exhibiting specific phylogenetic association with C. glomerans (86.6\% 16S rRNA sequence similarity; $14.8 \%$ sequence divergence) or $D$. detoxificans $(88.5 \% 16 \mathrm{~S}$ rRNA sequence similarity; $12.6 \%$ sequence divergence). Bootstrap resampling values (100 and 92\%) 


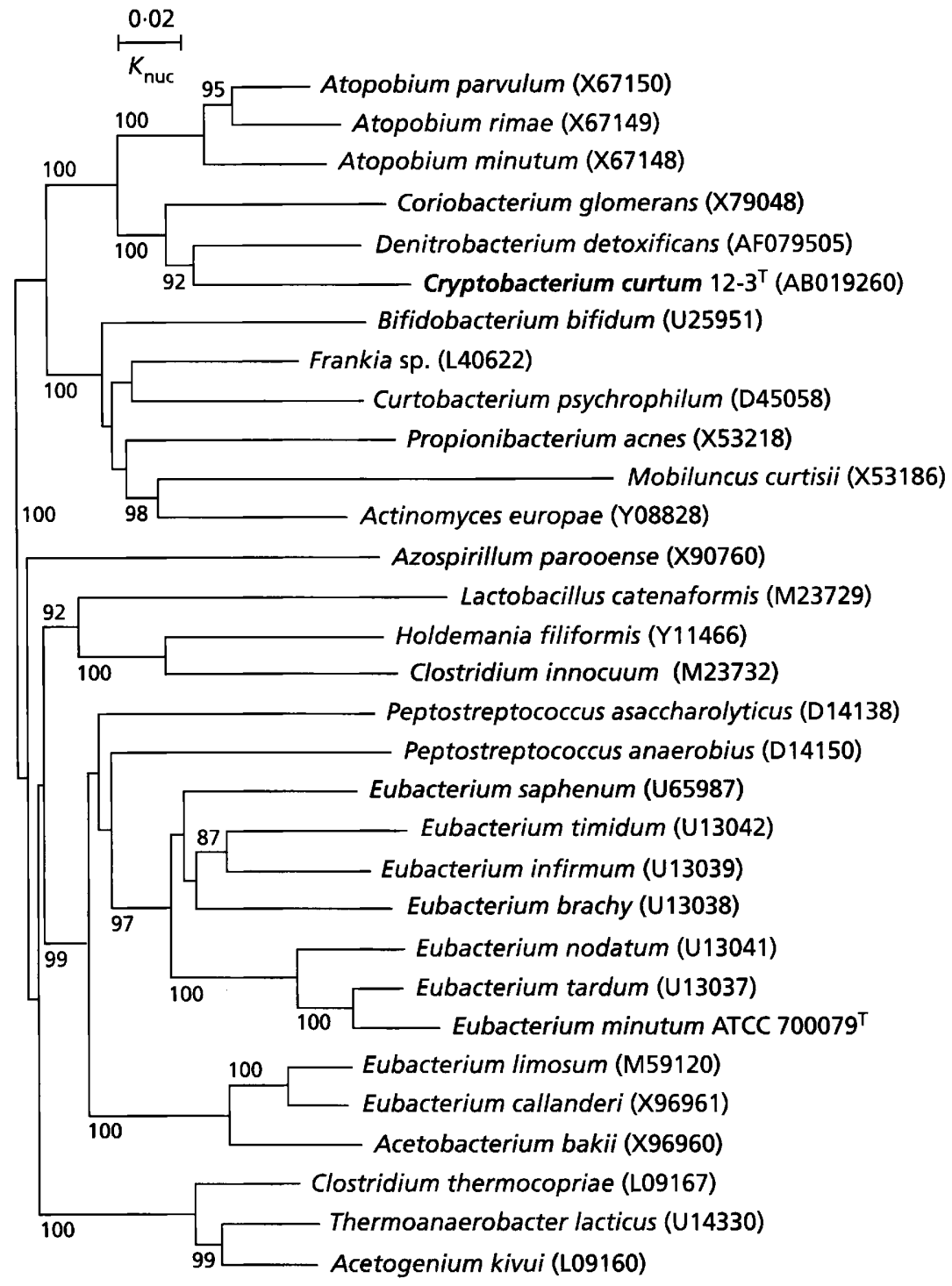

Fig. 3. Evolutionary tree based on 16S rRNA gene sequence comparison showing the phylogenetic position of Cryptobacterium curtum $12-3^{\top}\left(=\right.$ ATCC $\left.700863^{\top}\right)$. The dendrogram was created by using the neighbour-joining method. The numbers on the tree indicate bootstrap values (\%) calculated from 1000 replications. The nucleotide sequence accession numbers are in parentheses.

demonstrated these associations to be statistically significant.

From the 16S rRNA gene sequence comparisons, it is evident that the bacterium has a close phylogenetic relationship with $D$. detoxificans. Although the association between these taxa is statistically significant, a sequence divergence of $>10 \%$ suggests two phylogenetically closely related but nevertheless different genera. Also, it was shown that strain $12-3^{\mathrm{T}}$ had no close phylogenetic affinity with any of the other reference species examined (sequence similarities $<84 \%$; sequence divergence values $>17 \%$; individual data not shown). Our phylogenetic analysis based on comparisons of $16 \mathrm{~S}$ rRNA gene sequences indicates that strains $12-3^{\mathrm{T}}$ and KV43-B are clearly distinct not only from $E$. limosum, the type species of the genus
Eubacterium, but also from the other taxa established previously, which is consistent with the creation of a new genus.

It is noteworthy that all asaccharolytic Eubacterium species examined in this study, i.e. E. timidum, $E$. infirmum, $E$. saphenum, $E$. nodatum, $E$. tardum, $E$. minutum and E. brachy, showed no close phylogenetic affinity with E. limosum in the evolutionary tree. These results indicate that the genus Eubacterium may be incoherent and that these oral asaccharolytic Eubacterium species may need reassignment to different genera, as suggested by several authors (Cheeseman et al., 1996; Nakazawa \& Hoshino, 1993, 1994; Wade et al., 1994). At present, we have no information on the distribution, incidence and virulence of the novel species. 
On the basis of morphological and biochemical characteristics, SDS-PAGE and Western immunoblotting analysis, G $+\mathrm{C}$ content, DNA-DNA hybridization and $16 \mathrm{~S}$ rRNA gene sequence data, we believe that this bacterium merits classification as a new genus, for which the name Cryptobacterium curtum gen. nov., sp. nov. is proposed. The taxonomic description below summarizes the properties of the species.

\section{Description of Cryptobacterium gen. nov.}

Cryptobacterium (Crypt.o.bac.te'ri.um. Gr. n. kryptos hidden; Gr. n. bakterion a small rod; M.L. neut. n. Cryptobacterium a hidden rod-shaped bacterium).

Cells are short Gram-positive rods. Occasionally Gram-variable in stationary phase. Obligately anaerobic, non-motile and non-sporing. Catalasenegative. Asaccharolytic and no volatile end products in PYG. The DNA G $+\mathrm{C}$ content is $50-51 \mathrm{~mol} \%$. According to the almost complete $16 \mathrm{~S}$ rDNA sequence, the genus groups with the general cluster of actinomycetes of Gram-positive bacteria. Type species is Cryptobacterium curtum.

\section{Description of Cryptobacterium curtum sp. nov.}

Cryptobacterium curtum (cur'tum. L. neut. adj. curtum shortened, a shortened cell of this organism).

This description is based on the study of two strains isolated from oral cavities. Cells are very short, Gram-positive rods, obligately anaerobic, non-motile and non-sporing. Individual cells occur singly or in masses. Older cultures sometimes stain Gramnegative. On BHI-blood agar plates, minute colonies less than $1 \mathrm{~mm}$ in diameter are formed that are circular, convex and translucent even after prolonged incubation in an anaerobic glove box. Growth in broth media is poor with or without carbohydrates. No haemolysis occurs on BHI-blood agar plates. The cells are inert in most biochemical tests. Starch and aesculin are not hydrolysed; nitrate is not reduced. No liquefaction of gelatin occurs. Indole, urease and catalase are also negative. Ammonia is produced from arginine. The strains are non-fermentative and do not utilize adonitol, amygdalin, arabinose, cellobiose, erythritol, aesculin, fructose, galactose, glucose, glycogen, inositol, lactose, maltose, mannitol, mannose, melezitose, melibiose, rhamnose, ribose, salicin, sorbitol, starch, sucrose, trehalose or xylose. No metabolic end product is detected in peptone-yeast extract medium supplemented with glucose or PYG broth. Isolated from the periodontal pocket of a adult human with periodontal disease. The DNA $\mathrm{G}+\mathrm{C}$ content is $50-51 \mathrm{~mol} \%$. The type strain is $12-3^{\mathrm{T}}$ (= ATCC $\left.700863^{\mathrm{T}}\right)$.

\section{ACKNOWLEDGEMENTS}

This study was supported in part by grants-in-aid for scientific research 06044082, 07807166, 09470390 and 10922050 from the Ministry of Education, Science and Culture of Japan.

\section{REFERENCES}

Ando, N. \& Hoshino, E. (1990). Predominant obligate anaerobes invading the deep layers of root canal dentine. Int Endod J 23, 20-27.

Brook, I. (1983). Anaerobic bacterial bacteremia: 12-year experience in two military hospitals. $J$ Infect Dis 160, 1071-1075.

Brook, I. \& Frazier, E. H. (1993). Significant recovery of nonsporulating anaerobic rods from clinical specimens. Clin Infect Dis 16, 476-480.

Burnette, W. N. (1981). Western blotting electrophoretic transfer from sodium dodecyl sulfate-polyacrylamide gels to unmodified nitrocellulose and radiographic detection with antibody and radioiodinated protein A. Anal Biochem 112, 195.

Cheeseman, S. L., Hiom, S. J., Weightman, A. J. \& Wade, W. G. (1996). Phylogeny of oral asaccharolytic Eubacterium species determined by $16 \mathrm{~S}$ ribosomal DNA sequence comparison and proposal of Eubacterium infirmum sp. nov. and Eubacterium tardum sp. nov. Int J Syst Bacteriol 46, 957-959.

Edwardsson, S. (1974). Bacteriological studies on deep areas of carious dentine. Odontol Revy 25 (suppl. 32), 1-143.

Fanstein, V., Elting, L. S. \& Bodey, G. P. (1989). Bacteremia caused by non-sporulating anaerobes in cancer patients. Medicine (Baltimore) 68, 151-162.

Fukunaga, M., Takahashi, Y., Tsuruta, Y., Matsushita, O., Ralph, D., McClelland, M. \& Nakao, M. (1995). Genetic and phenotypic analysis of Borrelia miyamotoi sp. nov., isolated from the ixodic tick Ixodes persulcatus, the vector for Lyme disease in Japan. Int $J$ Syst Bacteriol 45, 804-810.

Gunsolley, J. C., Tew, J. G., Gooss, C., Marshall, D. R., Burmeister, J. A. \& Schenkein, H. A. (1990). Serum antibodies to periodontal bacteria. J Periodontol 61, 412-419.

Hill, G. B., Ayers, O. M. \& Kohhan, A. P. (1987). Characteristics and sites of infection of Eubacterium nodatum, Eubacterium timidum, Eubacterium brachy, and other asaccharolytic eubacteria. J Clin Microbiol 25, 1540-1545.

Holdeman, L. V., Cato, E. P. \& Moore, W. E. C. (editors) (1977). Anaerobe Laboratory Manual, 4th edn. Blacksburg, VA: Virginia Polytechnic Institute and State University.

Holdeman, L. V., Cato, E. P., Burmeister, E. P. \& Moore, W. E. C. (1980). Description of Eubacterium timidum sp. nov., Eubacterium brachy sp. nov. and Eubacterium nodatum sp. nov., isolated from human periodontitis. Int $J$ Syst Bacteriol 30, 163-169.

Hoshino, E. (1985). Predominant obligate anaerobes in human carious dentin. J Dent Res 64, 1195-1198.

Hoshino, E. \& Sato, M. (1986). Production and degradation of formate by Veillonella dispar ATCC 17745. J Dent Res 65, 903-905.

Hoshino, E., Ando, N., Sato, M. \& Kato, K. (1992). Bacterial invasion of non-exposed pulp. Int Endod $J$ 25, 2-5.

Katayama-Fujimura, Y., Komatsu, Y., Kuraishi, H. \& Kaneko, T. (1984). Estimation of DNA base composition by high performance liquid chromatography of its nuclease $\mathrm{P} 1$ hydrolysate. Agric Biol Chem 48, 3169-3172.

Laemmli, U. K. (1970). Cleavage of structural proteins during the assembly of the head of bacteriophage T4. Nature 227, 680-685.

Marmur, J. (1961). A procedure for the isolation of DNA from microorganisms. J Mol Biol 3, 208-218.

Martin, S. A., Falker, W. A., Vincent, J. W., Mackler, B. F. \& Suzuki, J. B. (1986). A comparison of the reactivity of Eubacterium species with localized and serum immunoglobulins from 
rapidly progressive and adult periodontitis. $J$ Periodontol 59, 32-39.

Meyer, S. A. \& Schleifer, K. H. (1978). Deoxyribonucleic acid reassociation in the classification of coagulase positive Staphylococci. Arch Microbiol 117, 183-188.

Moore, W. E. C. \& Moore, L. V. H. (1986). Genus Eubacterium Prevot 1938, 294 ${ }^{\mathrm{AL}}$. In Bergey's Manual of Systematic Bacteriology, vol. 2, pp. 1353-1373. Edited by P. H. A. Sneath, N. S. Mair, M. E. Sharpe \& J. G. Holt. Baltimore: Williams \& Wilkins.

Moore, W. E. C., Holdeman, L. V., Smibert, R. M., Hash, D. E., Burmeister, J. A. \& Ranney, R. R. (1982). Bacteriology of severe periodontitis in young adults. Infect Immun 38, 1137-1145.

Moore, W. E. C., Holdeman, L. V., Burmeister, J. A. \& Ranney, R. R. (1983). Bacteriology of moderate (chronic) periodontitis in mature adult humans. Infect Immun 42, 510-515.

Moore, W. E. C., Holdeman, L. V., Cato, E. P., Smibert, R. M., Burmeister, J. A., Palcanis, K. G. \& Ranney, R. R. (1985). Comparative bacteriology of juvenile periodontitis. Infect Immun $\mathbf{4 8 ,}$ 507-519.

Nakazawa, F. \& Hoshino, E. (1993). Immunological specificity of oral Eubacterium species. J Gen Microbiol 139, 2635-2640.

Nakazawa, F. \& Hoshino, E. (1994). Genetic relationships among Eubacterium species. Int J Syst Bacteriol 44, 787-790.

Poco, S. E., Jr, Nakazawa, F., Ikeda, T., Sato, M., Sato, T. \& Hoshino, E. (1996a). Eubacterium exiguum sp. nov., isolated from human oral lesions. Int J Syst Bacteriol 46, 1120-1124.

Poco, S. E., Jr, Nakazawa, F., Sato, M. \& Hoshino, E. (1996b). Eubacterium minutum sp. nov., isolated from human periodontal pockets. Int J Syst Bacteriol 46, 31-34.

Sato, T., Hoshino, E., Uematsu, H. \& Noda, T. (1993). Predominant obligate anaerobes in necrotic pulps of human deciduous teeth. Microbiol Ecol Health Dis 6, 269-275.
Sato, T., Sato, M., Matsuyama, J., Kalfas, S., Sundqvist, G. \& Hoshino, E. (1998). Restriction fragment-length polymorphism analysis of $16 \mathrm{~S}$ rDNA from oral asaccharolytic Eubacterium species amplified by polymerase chain reaction. Oral Microbiol Immunol 13, 23-29.

Slayne, M. A. \& Wade, W. G. (1994). The humoral response to asaccharolytic Eubacterium species in periodontitis. Microbiol Ecol Health Dis 7, 283-286.

Sundqvist, G. (1976). Bacteriological studies of necrotic dental pulps. Umeå University dissertation no. 7, pp. 1-92.

Tew, J. G., Marshall, D. R., Moore, W. E. C., Best, A. M., Palcanis, K. G. \& Ranney, R. R. (1985). Serum antibody reactive with predominant organisms in the subgingival flora of young adults with generalized severe periodontitis. Infect Immun 48, 303-311. Tolo, K. \& Schenck, K. (1985). Activity of serum immunoglobulins $\mathrm{G}, \mathrm{A}$ and $\mathrm{M}$ to six anaerobic oral bacteria in diagnosis of periodontitis. J Periodontal Res 20, 113-121.

Tolo, K. \& Jorkjend, L. (1990). Serum antibodies and loss of periodontal bone in patients with rheumatoid arthritis. $J$ Clin Periodontol 17, 288-291.

Uematsu, H. \& Hoshino, E. (1992). Predominant obligate anaerobes in human periodontal pockets. $J$ Periodontal Res 27, 15-19.

Uematsu, H., Nakazawa, F., Ikeda, T. \& Hoshino, E. (1993). Eubacterium saphenum sp. nov., isolated from the human periodontal pockets. Int J Syst Bacteriol 43, 302-304.

Wade, W. G., Moran, J., Morgan, J. R., Newcombe, R. \& Addy, M. (1992). The effects of antimicrobial acrylic strips on the subgingival microflora in chronic periodontitis. $J$ Clin Periodontol 19, 127-134.

Wade, W. G., Lewis, M. A. O., Cheeseman, S. L., Absi, E. G. \& Bishop, P. A. (1994). An unclassified Eubacterium taxon in acute dentoalveolar abscess. $J$ Med Microbiol 40, 115-117. 